\author{
$34^{\text {th }}$ Annual Scientific Meeting of the \\ International Society of Political Psychology (ISPP) \\ July 9th - 12th, 2011 \\ Istanbul, Turkey
}

Conference paper

\title{
Exploring the micro-politics of place: lifestyle migrants, collective identities and modes of belonging
}

\author{
Kate Torkington \\ Universidade do Algarve/Lancaster University \\ ktorking@ualg.pt
}

\section{Introduction}

This paper investigates one aspect of the politics of place and identity. I approach this by assuming that place-identity - i.e. the interrelationships between places and social identities is articulated in and through discourse, since places are given meaning and identity through discourse and these place-making activities both shape and are shaped by social identities, which are also discursively constructed to a large degree. According to Hopkins and Dixon (2006), a key task facing political psychology is "to recover the micro-politics of people's everyday constructions of place and space". This is important because the political significance of peoples' representations of place shape understandings of who belongs in (and, conversely, who becomes marginalised or even excluded from) particular places, the rights and freedoms that can be claimed and exercised, and the ways in which people relate to each other in spatialised contexts (ibid.). Drawing on texts from a variety of sources, including in-depth interviews I have conducted with British migrants in the Algarve in Portugal, ${ }^{1}$ this paper therefore aims to illustrate some of the ways in which versions of (being in) place are constructed and negotiated through discursive practices, and in particular the ways in which 'legitimate' collective belongings are established in relation to place.

\section{Lifestyle migration}

The overall context of my research is the social phenomenon of lifestyle migration. Within Europe, this typically involves relatively affluent northern Europeans moving to destinations in southern Europe that are strongly linked to tourism. The underlying motive for this type of relocation is the quest for what is perceived as a better and more fulfilling way of life (Benson $\&$ O'Reilly, 2009). The typical discursive representation of this form of migration (fuelled by television shows and other forms of the mass media) suggests that it is consumption-led, tourism-related and leisure-based. Buying one's own 'property' seems to be an essential part of this type of migration process, stemming from an ideology that associates the concept of 'home' and 'belonging' with land and property ownership. Within Europe, the favoured destinations are typically areas in southern Europe that are already developed for tourism and leisure, and which are perceived as affording the more relaxed and sociable lifestyle that northern Europeans associate with southern European cultures. In sum, international lifestyle migration is generally represented as a form of escape from the 'traps' of life in the country of origin, a 'living of the dream', the search for 'a place in the sun'. It could therefore be argued to be located within late modern, global, elitist and borderless social practices.

\footnotetext{
${ }^{1}$ This data was collected for my doctoral thesis on The discursive construction of place-identity: British lifestyle migrants in the Algarve (Lancaster University, Department of Linguistics and English Language).
} 
However, lifestyle migrants are people who have made a conscious choice not only about how to live but also about where to live (Hoey, 2005, 2009); thus whilst the lifestyle orientations and motivations of these migrants may differ, the one unifying factor of this broadly defined social group is their belief that a change of residential place will lead to what is perceived as a better and more fulfilling way of life. Fundamental to the concept of lifestyle migration, then, is the interrelationship of lifestyle and place; the place must be perceived to 'fit' with the sought-after lifestyle.

When considered from this perspective, it may well be viewed as an apolitical expression of individual lifestyle practices, albeit within the paradigm of privileged, or elite, forms of mobility. However, lifestyle migration has inevitable impacts on local places, particularly in destination places that are attracting increasing numbers of such migrants. The case of Spain stands out as a warning as to what can happen when tourism-related forms of migration are allowed, and even actively encouraged, to develop unchecked by national and regional policy makers. Although studies by Spanish academics have pointed to situations of environmental unsustainability, increasing difficulties with managing public resources and the problems associated with excessive economic dependence on the activities associated with 'residential tourism' (Mantecón, 2010), this type of migration is legitimated by discourses in the public sphere that define it as an essentially tourism-related - and thus economically beneficial phenomenon (Huete et al., 2008; Mantecón, 2010; M azón et al., 2009).

Northern European lifestyle migrants are therefore generally viewed by their southern European hosts as 'desirable' migrants due to their perceived economic and socio-cultural capital. Yet their integration into local communities is often minimal; many are unable to speak the local language and live in seemingly self-sufficient communities with little or no contact with their 'hosts'. The question arises as to how these migrants construct modes of belonging in relation to their adopted home-place and how they relate to the other social groups with whom they share it. My concerns, therefore, in investigating the relationships between place and identity in the context of lifestyle migration, are a) to explore how lifestyle migrants position themselves (and others) in relation to local places; b) how lifestyle migrants are positioned by discourses in the public sphere; c) how these positionings index broader sociocultural and ideological values and d) how this impacts on the micro-politics of place.

\section{The micro-politics of place}

The politics of place can be understood and explored in a variety of ways, from forms of involvement in local governmental and institutional politics to more informal participation in social movements. ${ }^{2}$ However, I will use the concept in relation to the construction of identities. Following M odan (2007), I take the (micro-)politics of place to mean how versions of place are created through discourses that construct identity. I am particularly interested in the ways in which 'legitimate' (or, conversely, marginalised/excluded) identities are discursively constructed within places, and how this impacts on notions of belonging.

\footnotetext{
${ }^{2}$ Janoschka (2008) gives an excellent account of the ways in which northern European migrants in Spain integrate themselves and exercise leadership via local politics. The ways in which they do this range from informal involvement in social movements and grassroots activism to formal representation in local government. In the Algarve, I have not observed much participation in local politics at the institutional level among lifestyle migrants, although there is a fair amount of involvement at the broader level of social causes, for example through charity or voluntary work and through associations that are involved in environmental/conservation causes and such like.
} 
By exploring how particular representations of place are established through discourses that simultaneously construct identities for both places and the people who inhabit them, this approach therefore reveals the ways in which particular social groups make claims to 'belong' in a place and on what basis these claims are made. The idea of power geometries (Massey, $1993,1999)$ encapsulates the ways in which different social groups are positioned in distinct ways in relation to the flows and interconnections that characterise both the globalised world and local places. What I want to suggest is that the exercise of power relations which shape power geometries in particular places is, to some extent, located in the discursive practices that simultaneously constitute and are constituted by social identities and the identities of places.

\section{Belonging}

The interconnected processes of globalisation and migration are compelling a rethinking of conceptual frameworks for understanding such facets of the social and political world as citizenship and identity (Papastergiadis, 2000), particularly in terms of who 'belongs' in a place. In today's increasingly mobile world, belonging is clearly no longer necessarily an attribute of being 'born and bred' in a place. Rather, a sense of elective belonging (Savage et al., 2005) can arise when a place is perceived as valuable due to its congruence with lifestyle and life-project requirements (Giddens, 1991), one's repertoire of 'ideal' or 'possible' selves (Markus \& Nurius, 1986), and its connection to other significant places. In other words, contemporary modes of belonging are often not only elective, but also relational, in that they are actively constructed through social practices that articulate spatial attachments, social positioning and networked relationships. Importantly, to achieve a sense of elective belonging in a place, this must somehow be constructed as being legitimate, for otherwise one remains an 'outsider' whatever one's affective relationship towards that place might be. My argument is that this legitimacy is partly achieved through individual and collective spatial positionings (both literal and metaphorical) in discourse, and that these positionings both arise from and feed into the networks of social representations (Moscovici, 1984, 2000) that underlie broader ideologies. Since such positionings are inevitably ideological in nature, they simultaneously emerge from and contribute to the politics of local places.

\section{The research site}

The Algarve, in Portugal, has become firmly established as a tourist destination for northern Europeans. It is also a flourishing destination for lifestyle migration. It is currently estimated that there are around 40,000 British nationals living in the Algarve, ${ }^{3}$ both part-time and fulltime. If we consider that this is equivalent to around $10 \%$ of the regional population, it is quite a significant figure.

The first international tourists in the Algarve were British; likewise, the first lifestyle migrants. Small enclaves of British seasonal settlers (often ex-colonials) began to appear in the 1920s. In an early travel book, Gibbons (1936: 173) noted that:

there are growing up tiny colonies of exiles; one could live like a prince down that way for very little money indeed, of course, besides having the feeling of being a prince who had dodged the English income tax.

By the 1960s and the beginning of the 1970s - that is, before the 1974 Revolution which overturned the almost 50-year-old dictatorship of the Estado Novo (New State) regime and paved the way for modern democracy in Portugal, and before Faro Airport became a busy international gateway to the region - other groups of British were also discovering the

\footnotetext{
${ }^{3}$ http://ukinportugal.fco.gov.uk/en, accessed 21 April 2009.
} 
pleasures of life in a region that was all but cut off from the rest of Portugal and Europe. In her recently published memoir (Grainer, 2004: 12-13), a long-time British resident in the Algarve describes these 'pioneers' who came to enjoy 'a different lifestyle':

Many were ex-servicemen who had become too used to the sun to move back to the UK; some (...) were writers or artists who needed inspirational surroundings to get ideas. Quite a number were famous stars of stage, screen and TV or pop stars who wanted to be able to sit at a café without being recognised. A large proportion were the sons and daughters of the wealthy and noble (...) I met a runaway heiress and her hairdresser boyfriend, several millionaires with dodgy connections and we even had our own society hostess who ran our local Discotheque and today fixes the social life of the jet set in London.

However, it was with the huge construction projects of holiday aldeamentos ('villages') along the coast in the 1980s that 'residential tourism' really began in earnest, leading to exponential increases in British nationals taking up part-time or permanent residency over the past two decades. It is worth noting that even today, the phenomenon is perceived (by both migrants themselves and by their 'hosts') as being particularly related to wealthier sections of British society.

My specific research site is an area that corresponds to the Freguesia (Parish) of Almancil in the central Algarve. This area is known among the lifestyle migrant community as the 'Golden Triangle', because it is reputedly where the most expensive land and properties are. This 'triangle' includes the small town of Almancil, a few kilometres inland, and the well-known, upmarket coastal resort areas of Vale do Lobo and Quinta do Lago, among others. The town of Almancil itself is a very ordinary sort of town, serving as a support centre for the tourism developments along the coast. Until the 1960s the town was more affected by outward than inward migration - for example, more than half the population emigrated to Venezuela in the mid C20th. These days, however, it is characterised by different migrant communities, notably those originating from the former Portuguese colonies in Africa, and, more recently, Eastern Europe. The multicultural texture of the town is reflected in the fact that 30 different nationalities make up around one quarter of pupils in state schools (the largest groups being Cape Verdian, Romanian and Ukrainian) (Cardoso Sousa, 2007). The fact that the town is also characterised by the relative poverty of certain sections of its population is evident when we consider that over $25 \%$ of state school pupils receive financial help from the Serviços de Acção Social Escolar (Social Support in Schools Services), which is much higher than the national average (ibid.).

In stark contrast, the coastal belt of the Freguesia and the rural areas surrounding the town have become increasingly populated by wealthy northern European migrants and secondhome owners. As noted above, the so-called 'Golden Triangle' is considered to be one of the most prestigious addresses for northern Europeans re-locating to Portugal, and the real estate and property development sector has boomed in this area over the last three decades. This is 'officially' backed by the Plano Estratégico Nacional de Turismo (National Strategic Plan for Tourism) ${ }^{4}$ which specifies the development and marketing of 'integrated resorts' (i.e. resorts built for both tourist and residential purposes, with leisure facilities such as golf courses and spas), as one of the top ten strategic products for the development of tourism. In 2005, 1143 residents from the UK, Ireland, Germany and Holland were registered as living in the

\footnotetext{
${ }^{4}$ Ministério da Economia e da Inovação (2007) Plano Estratégico Nacional de Turismo. Lisboa: Turismo de Portugal. Available online at www.turismodeportugal.pt (retrieved 02.04.10).
} 
Freguesia, ${ }^{5}$ a figure that equates to $10 \%$ of the population. The private, fee-paying International School São Lourenço, located between Almancil and the coastal resort of Vale do Lobo, had over 200 northern European students enrolled (mostly of British nationality).

\section{Positioning northern European migrants}

The term 'lifestyle migrant' appears to be currently limited to academic discourse; it is therefore unlikely that it is used as a self-referential strategy by migrants themselves and it rarely appears in other forms of public discourse such as that emanating from the mass media or official policy documents. This section considers how such migrants are positioned through referential discourse strategies and the effect of this in terms of belonging in place.

\subsection{Residential tourists}

In Portugal, the umbrella term employed by public and private sector organizations as well as by some academics to describe this form of migration is turismo residencial (residential tourism). This oxymoron confers the ambivalent status of being considered as much tourist as resident and seems to make no distinction among seasonal visitors, second-home owners and more permanent settlers. The apparent contradiction in terms is problematic for those who consider themselves to be living full-time in the Algarve. It is not surprising therefore that the majority of British migrants I have talked to in the Algarve strongly reject the transient identity implied by the identification 'tourist', referring to themselves rather as 'residents'.

Not being a tourist seems to be fundamental to the positive presentation of the self for lifestyle migrants, as has been repeatedly noted in ethnographic studies of the phenomenon (e.g. Gustafson, 2002; O'Reilly, 2000; Waldren, 1996). In my interview data, I have found that the not-a-tourist repertoire involves more than simply affirming that one is not a tourist, or nominalising 'tourists' as an out-group. One of the more subtle ways of doing this identity work involves the discursive plotting out of spatial relations by the linguistic marking of 'boundaries' between tourist and non-tourist space. Some places are nominalised as being specifically for tourists by compound nouns such as 'tourist bars', 'tourist restaurants', 'the tourist market'. Other places are also constructed as 'non-tourist' through relational spatial formulations, for example by representing one's neighbourhood as being spatially situated away from tourist activity: one participant told me 'I think this is ideal really where we live here because we're not on the tourist track'. By discursively constructing her home-place in this way, this speaker is also emphasizing being away from the movement of tourists, therefore suggesting a more stable and fixed sense of place. This is echoed by another participant, who positively evaluates her neighbourhood as being 'away from that holiday coming and going'. Clearly, by constructing the home-place as a non-tourist space, one can stake a greater claim and a greater commitment to belonging in a place than those who are merely passing through.

\subsection{Immigrants}

The generic term 'residential tourist' is restricted to northern Europeans. The label 'immigrant' is reserved primarily for those of African, Asian, or Brazilian origin (i.e. migrants from the former Portuguese colonies) as well as eastern Europeans, so when 'immigrants' are discussed in the Portuguese media or even in academic circles, the term hardly ever includes northern Europeans (O'Reilly (2003) and Mantecón (2010) have noted the same discursive phenomenon in relation to migration in Spain). This difference in referential strategies doubtless reinforces

\footnotetext{
${ }^{5}$ Source: SEF.

${ }^{6}$ This categorisation is reinforced by the popular and widely read English language newspaper The Algarve Resident, which not only carries the term in its title, but also refers repeatedly to 'residents' in its texts.
} 
differences in the way these migrant groups are viewed by Portuguese society: as in much of Europe, 'immigrants' certainly have a problematic status in both media and political discourse. One of the connotations of the noun 'immigrant' is the implication of a fairly permanent move from one country to a destination place, which can then activate social representations of the destination place becoming overcrowded and 'burdened' (see section 10 below) with people who have no real claim to be or to belong in the place. On the other hand, the lack of fixity in place suggested by the term 'resident tourist' sidesteps any such issues.

I have, however, come across newspaper references to 'imigração/imigrantes de luxo' (luxury immigration/immigrants) following the dissemination of the results of a survey by The Portugal News ${ }^{7}$ in 2006. This provoked headlines in the Portuguese press such as 'Portugal na rota da imigração de luxo' (Correio da Manhã, 25/01/06) and 'Existem 250 mil «imigrantes de luxo» em Portugal' (Expresso, 31/01/06). This modification of the noun clearly serves to stress the privileged/elitist evaluation of this type of migrant and to demarcate a group boundary that does not include other immigrant groups who might be nominalised in other ways.

\subsection{Positioning lifestyle migrants through discourse in place}

Besides the generic discourses in the public sphere, there also more localized discourses circulating in specific destination places, including discursive practices that actually help to physically construct the place itself, its meanings and identities, and the identities of the people who live in it.

One of the most striking aspects of the landscape as one moves around the 'Golden Triangle' area is the predominance of roadside billboards advertising land and property sales/development in English. As a marker of 'social allegiance' or group identity, code (language) choice is thus used strategically to construct an ingroup of English-speakers (or, at least, those who understand English) who are positioned not merely as the major target group for buying property in this area, but also as part of an exclusive, elitist collectivity. Although 'elite' membership status is clearly grounded in economic privilege, it is not a clear-cut, structural social category. An elite identity is an ideological subject position; it is semiotically achieved and enacted through social practices, including discourse (Thurlow \& Jaworski, 2006). Membership is therefore relatively open - and through the repetition and routinization of discursive practices such as the processes of symbolic differentiation - including, in this case, through the foregrounding of English rather than the local language in these highly visible billboards) - elitist, privileged, collective identities are reproduced and reinforced.

The discursive construction of an elite place-identity through symbolic differentiation is also realized through the actual texts of these billboards. One of the recurrent lexical themes in the texts of these billboards is that of 'exclusivity'. The lexeme 'exclusive' and its derivatives appear constantly on the billboard straplines (e.g. 'EXCLUSIVITY AWAITS YOU'). Further examples of discursive strategies that are effectively stylizing an elitist collective place-identity include ample use of hyperbolic evaluative words ('luxury'; 'stylish'; 'prestigious'; 'superb'; 'exceptional') and lexical choices (to describe the 'properties' on sale) that have lifestyle connotative meanings (Myers, 1994: 71), e.g. 'villa', 'apartment', 'townhouse', 'manor house'. Visual images of a leisure-based lifestyle are persistent: luxurious homes with swimming pools, swathes of verdant green golf courses, beaches at sunset. The people portrayed are generally engaged in the types of activities associated with these lifestyle signifiers - playing golf, relaxing by the pool, strolling hand-in-hand through gentle surf. Besides being intertextual references from typical tourism promotional media, these types of images also activate connotative cultural schemata that suggest privileged, global identities.

\footnotetext{
${ }^{7}$ An English language newspaper with a wide circulation among northern Europeans in Portugal.
} 
In sum, the combination of code choice and discourse strategies results in a "composite of connotations" (van Leeuwen, 2005: 147) from which a collective place-identity based on privilege, distinction/difference and exclusivity can be inferred. In this way, this aspect of the landscape functions as a kind of interface between between place, identity and power relations; as part of the process of place-making, these texts impact upon the discursive construction of the social identities of those who wish to stake a claim to the place by material investment in it. It thus contributes to the micro-politics of place, by shaping the identity of the 'Golden Triangle' as a place where English-speaking people have their homes. A sense of place with boundaries (symbolic and ideological rather than physical, but strongly delineated nonetheless) is being constructed for these 'outsiders' who have no real sense of physical, cultural or ancestral ties with the place they have chosen as home. An ideology based on consumer culture that equates 'home' with private land or property ownership is being reinforced to induce feelings of elective belonging which are simultaneously both integrating (through ingroup membership) and exclusionary, since a 'frontier' of difference is constructed leading to a powerful sense of distinctive social identity. In short, lifestyle migrants are being positioned as having a claim to the place based on economic investment and social privilege. Whether or not this identity position is taken up by lifestyle migrants in talk is discussed below.

\section{Discourse and ideology}

Discourse is inevitably linked to ideology. Van Dijk (1998; 2009) defines ideologies as the underlying social beliefs and values that form the basis of the organization and control of social representations shared by members of a group. As such, ideologies have both cognitive and social properties, and are deployed (typically through discourse) by different social groups to make sense of the way the social world works and to regulate social practices. Ideologies support particular representations of the world and thus serve to "rationalize, legitimate, maintain and (re)produce particular (...) economic, social and power relations within a society" (Augoustinos et al., 2006: 272).

It is important to point out that there is no direct link between discourse and ideology (van Dijk, 2009: 79). The relationship is mediated by the underlying network of social representations upon which individuals draw in order to organise their worldview, or at least the way in which they want to project it in a particular context. For example, social representations about the equality (or inequality) of ethnic groups around the world organize socially shared opinions about 'legitimate' forms of migration. These opinions both shape, and are shaped by, specific event models which involve specific participants and their actions. However, the ideologies expressed in utterances are not necessarily straightforward, but may be 'dilemmatic' (Billig, 1997). Thus we can suppose that individuals have their own personal versions of a shared social belief system or ideology which account for the differences and even contradictions that can be traced in the expression of ideologies in empirical research (van Dijk, 1998: 30).

\section{Place-identity and ideological dilemmas}

It cannot be assumed that speakers will be consistent in the ways in which they employ representations to construct their versions of the social world or indeed to index their social identities. Some degree of inconsistency is an inevitable feature of talk. The participants in my research, in general, stress their positive affective alignment with the place they call home, and their overall self-positionings work to construct a mode of elective belonging that ties in with the self-image they want to project. In most cases, this self-positioning is individual positioning, that is, speakers want to be seen primarily as individual agents rather than as members of a social group (for example as part of the 'British abroad' collective). The onus of their identity work therefore is on constructing a coherent narrative of the self, as part of the reflexive project of the self (Giddens, 1991), although for the adult speakers, this 'self' is not 
entirely individual since they also index 'relational selves' (M ason, 2004) through 'we-speak' to emphasize their family relationships. Nonetheless, these positionings are primarily taken up as a means of enacting personalised attachments that feed into modes of elective belonging. In other words, the speakers want to project themselves as active agents in relation to their lived experiences, including their relationships to place, especially in terms of the 'fit' between self, lifestyle and place.

It may well be that individual identities 'exist', since people clearly have distinct physical and cognitive/psychological referents. However, it is equally important to bear in mind that the individual does not exist in isolation from the social world, and that identity is always constructed in and through social interaction and within broader socio-cultural and historical contexts. This means that individual identities cannot be neatly separated from collective identities, for the process of identity formation necessarily involves interaction not only between individuals, but also between individuals and social groups. Thus, rather than being qualitatively different, as is sometimes assumed in sociological literature, the two dimensions of identity are mutually constituted and intertwined (Triandafyllidou \& Wodak, 2003). However, for analytical purposes, it is often helpful to examine how speakers work to position themselves (and others) as individuals and/or as members of social groups.

In the final part of this paper, I look specifically at the 'trouble' (Wetherell, 1998) in identity work that can occur when collective positionings seem to conflict with individual positionings, and how speakers work to 'repair' such trouble (Taylor, 2010) and resolve dilemmas. I also discuss what an analysis of the collective dimension of place-identity reveals about broader underlying ideologies.

\section{The 'language issue'}

A salient shared characteristic of the participants in this research is that, like the majority of British lifestyle migrants in the Algarve, they use English as the primary means of communication in their everyday lives. In other words, they have no more than a very elementary working knowledge of the Portuguese language. It might well be thought that this language issue constitutes a problem for migrants, since the language 'barrier' that arises from an inability to speak the local language surely constitutes a huge obstacle to a sense of belonging in a place.

Much of the sociological literature on intra-European lifestyle migration has indeed flagged hopes of interaction and even integration with the 'host' community as part and parcel of migrants' expectations for a better quality of life (e.g. Benson, 2009, 2010; Huber $\&$ O'Reilly, 2004; O'Reilly, 2000). However, it has also been noted that more often than not these hopes are dashed, for when expectations meet reality, migrants are confronted with their limited knowledge of the local setting, the way of life and the local language (O'Reilly \& Benson, 2009). The participants in my research certainly stress their difficulties in learning the Portuguese language. Yet other groups of migrants, for instance those from eastern European countries, do not seem to experience the same difficulties. There is perhaps a simple explanation for this: whilst migration for economic purposes generates a need to learn the local language in order to work, lifestyle migrants generally have no such 'instrumental' (Gardner, 1985) motivation. This lack of necessity is further compounded by the fact that English is so widely spoken in the Algarve. M ainly due to tourism development and the strong dependence of the local economy on tourism, ${ }^{8}$ combined with the growing numbers of northern European lifestyle migrants in

\footnotetext{
${ }^{8}$ Tourism activities account for almost $50 \%$ of the regional wealth, while more than $70 \%$ of the region's working population are employed in the service sector (M artins de Brito et al., 2010).
} 
many areas of the region, seemingly everyone has some command of English these days, ${ }^{9}$ and English is routinely used as a language of communication. This is a common repertoire in the data ('there's no need to speak Portuguese'; 'everyone here speaks English' and so forth). However, the fact that most participants talk at length about the language issue indicates how fundamental it is to their lived experience in the local place. Yet whilst most agree that there is some sort of moral obligation to learn Portuguese ('I know you should, if you're gonna live here try'; ' 'you know we've chosen to move to their country, and so really we should learn'), the fact remains that they do not learn it.

\section{Collective positioning in the interview data}

What stands out from the data is that this language issue seems to be a trigger for switches in positioning from an individualised, 'happy and successful' migrant, to a more 'defensive', collective self-positioning. To illustrate, the brief analysis that follows traces how what starts as a personal issue, i.e. living in Portugal but not speaking the Portuguese language, ends up as an ideological dilemma which the speaker attempts to resolve by addressing the legitimacy of different types of migration mobilities. Extract 1 comes at a point in the interview when I (KT) have just asked Jean ${ }^{10}$ if she can speak any Portuguese and she has admitted that she cannot, despite having lived in Portugal for thirteen years.

\section{Extract 1}

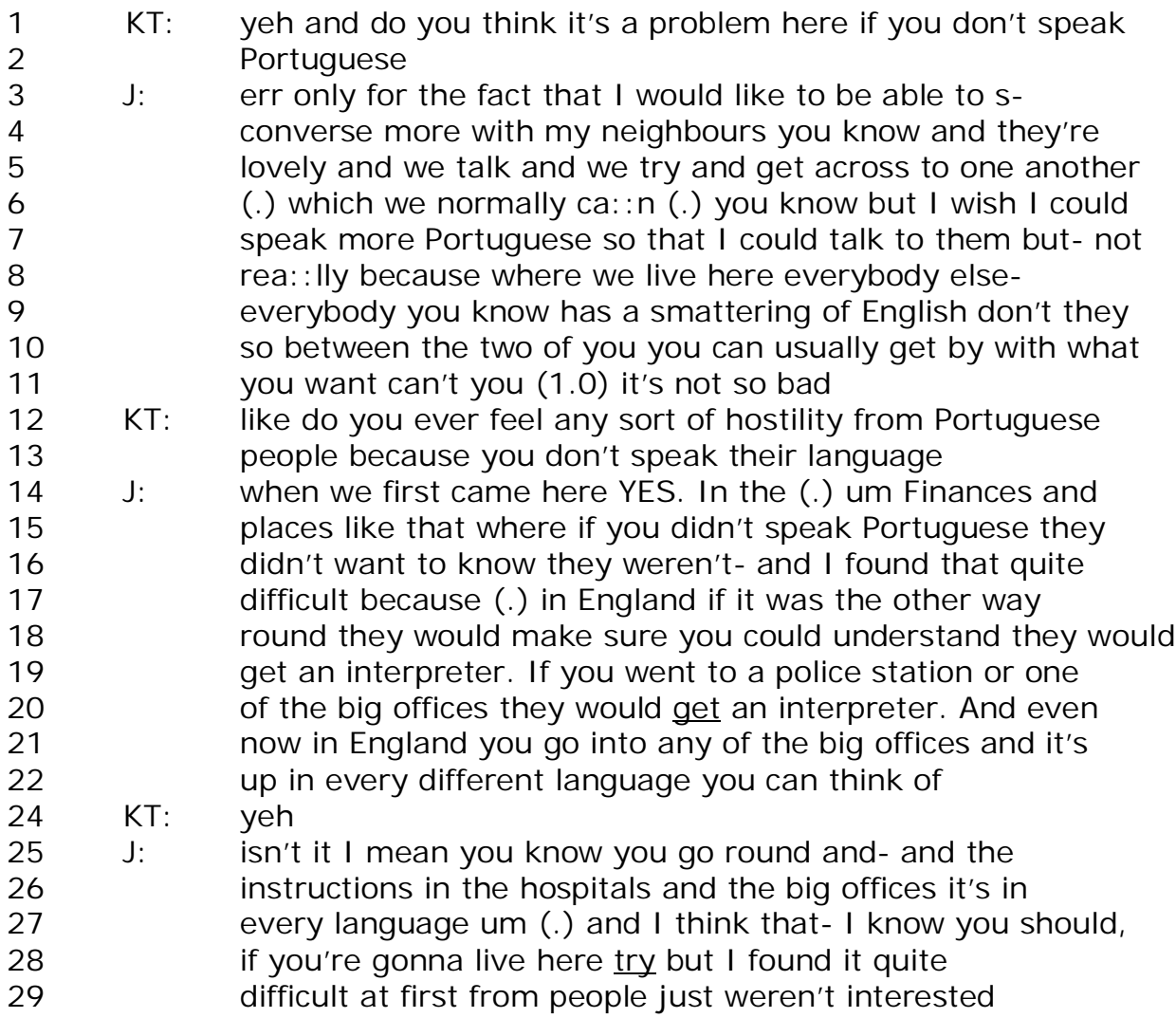

\footnotetext{
${ }^{9}$ Other factors of course have played a part in the spread of English in the region, but the situation in the Algarve is not mirrored in other regions of Portugal where tourism is not so evident or economically important.

${ }^{10}$ All participant names are pseudonyms.
} 
Her initial response is to limit the 'problem' to the scale of her neighbourhood; she concedes that if she could speak more Portuguese she would be able to talk more to her 'lovely' Portuguese neighbours. However, this creates trouble in her preferred identity position as a successful migrant, since it suggests a potential obstacle to belonging. She attempts to repair this by stating that 'where we live here' (presumably her immediate neighbourhood), 'everybody you know has a smattering of English' (line 9) so 'you can usually get by'. Her coda (line 11) is an evaluation of the situation as being "not so bad", therefore dispelling the idea of not speaking Portuguese as being particularly problematic.

However, as the interviewer, I seem not to accept this resolution and I rephrase my previous question by asking her if she ever feels any 'hostility' from Portuguese people due to her not speaking 'their' language (lines 12-13). In doing so, I have taken the emphasis away from the implication that Jean herself (as agent) might have caused the 'problem' by not speaking Portuguese, and re-positioned her as a possible 'victim' of hostility. Furthermore, I have positioned the Portuguese language as belonging to them, the outgroup, which seems to lessen the responsibility towards learning it if one is not Portuguese oneself. The effect of my re-phrasing of the question is quite dramatic. Jean answers this time with an emphatic affirmative, although she does distance her position through temporal deixis 'when we first came here YES' (line 14). Looking back to that time, she recalls the difficulties she faced in public offices such as the 'Finances' (tax office) where the staff were indifferent towards those who could not speak Portuguese (line 16). Her representation of what would (hypothetically) be the comparable case in England is that efforts would be made; an interpreter would be made available, for example. Furthermore, she argues, in the public offices in England information is posted up in 'every different language you can think of'.

She seems to realise that her greatly exaggerated argument does not hold weight, as her subsequent reformulation is less confident, marked by various hedging devices. She then resorts to defensive rhetoric, by anticipating and acknowledging a counter argument ('I know you should, if you're gonna live here try', lines 27-28), although the use of the impersonal/generalised you rather than the first person pronoun signals a distancing of the self from the proposition. Finally, with the countering but, she returns to her original line of argument (prompted by my re-phrased question), that she was 'victim' to the indifference of the Portuguese staff - who 'just weren't interested'. In this way, she attempts to resolve the trouble in her own identity position firstly by juxtaposing a more intimate place (her neighbourhood with its 'lovely' Portuguese inhabitants) with the impersonal, public space of the 'Finances', and secondly with the implication that any 'difficulties' originate from them, the Portuguese outgroup, rather than from herself as either an individual or as part of a (British migrant) collective. The irony is that it is fairly evident that British lifestyle migrants in the Algarve, as a social group, 'just aren't interested' in learning the Portuguese language.

Later in the interview (extract 2 below), Jean returns to the repertoire of the indifference towards the northern European migrants. Her argument now is that such migrants are 'here' primarily because of the 'sunshine', which costs nothing and yet 'we' are 'bringing in the money for you' and are thus economically beneficial. The implication is that as such, 'we' are deserving of respect, which could be shown by more willingness (on the part of the Portuguese 'hosts') to help in such matters as overcoming the language barrier. Once again, her argument is based on straw man fallacies (cf. Reisigl \& Wodak, 2001) including what she represents as being the case in England, where, she claims, 'it's totally the other way round' (line 13). There, in Jean's view, migrants bring no economic advantage to the country; on the contrary, they are an economic burden, 'draining the system' (line 14). Yet in contrast to the 'indifference' shown in Portugal, 'they' (the British state authorities?) not only 'let them [migrants] in' and 'welcome' them, they actually 'bend over backwards' to help them. 


\section{Extract 2}

\begin{tabular}{|c|c|}
\hline $\begin{array}{l}01 \\
02\end{array}$ & $\begin{array}{l}\text { the trouble is you tend to get a bit cross cos you think to } \\
\text { vourself well hang on a minute if you didn't have the }\end{array}$ \\
\hline 03 & sunshine here you wouldn't ha: : ve the- you wouldn't have all the \\
\hline 04 & ex-pats that you get from all the different countries not just \\
\hline 05 & England but all the different countries (.) which brings \\
\hline 06 & in a lot of money and we found (.) and I think that annoys \\
\hline 07 & you cos you think to yourself well we're bringing in the \\
\hline 08 & money for you and we're trying to (.) bring in money for \\
\hline 09 & you and in England it's totally the other way you get \\
\hline 10 & people coming into England and they're draining the system \\
\hline 11 & (.) yet they're still welcome in they let them in and they \\
\hline 2 & let them drain the system and they- they do everything they \\
\hline & bend over backwards for them (.) \\
\hline
\end{tabular}

The anti-immigrant discourse which has become so hegemonic in certain sections of the British media and society (see, for example, Baker et al., 2008; Gabrielatos \& Baker, 2008) is clearly reproduced in this extract and hardly needs to be commented on here. What is interesting is the speaker's switching of self-positioning from part of the English collective in Portugal (we, here, lines 7-8) to a member of a national collective speaking from a position where the nation, as a located, bounded entity, is conceptualised as being at deictic centre. This is signalled in line 10, where she comments on people 'coming into England'. ${ }^{11}$ This type of transposed deictic framework (i.e. deictic centring on the nation - rather than the speaker's current location - and by extension the collective national self) marks an ideological perspective (Chilton, 2004: 123) as it signals her self-inclusion as a 'legitimate' member of the social group who is entitled to be 'in' England. As Wieczorek (2009) discusses, clusivity (expressing inclusion and exclusion) in discourse does not only operate at the level of personal pronouns but also includes a number of linguistic means of communicating belonging (or not) that rest on the spatially-oriented image schemata (Johnson, 1987) of CONTAINER (with elements inside/outside) and CENTRE-PERIPHERY (with elements moving inwards/outwards). In extract 2 above, Jean makes a clear distinction between people simply 'coming' into England (from the periphery) and those who 'bring money' into Portugal and are therefore represented as actively contributing to the common good.

This speaker is not the only participant to make this kind of deictic transposition, as can be seen in extract 3, where M arion refers to people 'coming in' to England (lines 5, 8):

\section{Extract 3}

01 KT: why- why do you think so many people are moving over here

02 or-

$03 \quad$ M: well I think um (.) I think the fact that England is not

04 England any more in as much as (.) you've got such a lot of

05 um people coming in <I mean I say that and I'm here! but

06 you know they've got such a lot of refugees and actually I

07 do think the English get pushed to the back of the queue

08 by all these people coming in whereas here(.) they do look

09 after their own here don't they whereas in England you know the

10 English seem to be (1.0) and all the foreigners seem to get

11 whatever's going

\footnotetext{
${ }^{11}$ The deictically anchored verb 'come' usually denotes movement from there to here. If the speaker is not physically located in the place which corresponds to the discursively constructed 'here', a conceptual projection seems to have occurred, indicating a strong shift in perspectivisation.
} 
What is particularly interesting in this extract is the way in which this racist, anti-immigrant discourse is reproduced to construct an implicit argument for what count as legitimate forms of mobility and settlement in a place. Whilst 'England is not England' any longer (line 3-4) because of all the 'people coming in', the dilemma is that the same argument could be applied to the Algarve; indeed the irony is evident (as the speaker acknowledges in lines 5-6). This is doubtless why she then recasts the migrants entering Britain as 'refugees' (and later in the interview as 'illegals'). ${ }^{12}$ The interview data suggests that many of the participants draw on a social representation that constructs legitimate forms of migratory mobility as based on entering a place with money to spend or invest, i.e. with economic power. This then concedes certain rights - not only the right to be in that place, but also the right to be respected and even the right to waive certain moral 'obligations', such as learning the local language. This neo-colonialist discourse implies that with economic power, one can stake a legitimate - and by extension privileged - claim to belonging in a place.

On the other hand, there are frequent discursive moves to distance the individual self from the social representation of northern European migrants as a self-marginalised collective, living extravagant lives of leisure and luxury and making 'a place in the sun' for themselves. Jean, for example, jokingly describes her lifestyle as 'very poor!' and goes on to affirm 'yes I mean we don't live that way of life I mean we can't afford it'. More implicit comparisons between oneself and other lifestyle migrants in terms of economic privilege are made through reference to specific places where the wealthy are supposed to live, such as 'you know it's quite um a rich area down in Quinta', thus projecting the characteristics of the (northern European) inhabitants onto the place. However, as a social group, the Portuguese are invariably represented as being lower down the scale of economic power, with comments such as: 'I mean there'll not be a lot of Portuguese that have a lot of money do they you know which is a bit sad really'.

The stereotypical representation of the 'local' people as being materially 'poor' is often implicit in spatialised accounts that draw on a representation of Portugal as a developing country. Lynn compares the Algarve with England in terms of development (extract 4).

\section{Extract 4}

$\begin{array}{lll}01 & \text { L: } & \text { uhm I think that (3.0) Portugal or the Algarve is becoming } \\ 02 & & \text { like England, more and more } \\ 03 & \text { KT: } & \text { mm hm } \\ 04 & \text { L: } & \begin{array}{l}\text { because we've got all McDonalds <when we came- when we } \\ \text { arrived there was still only two McDonalds, Albufeira and } \\ 05\end{array} \\ 06 & & \text { Faro } \\ 07 & \text { KT: } & \text { mm hm } \\ 08 & \text { L: } & \text { uhm so we just saw the last bit of it being (.) more you } \\ 09 & & \text { know backwards and I think now, it's speeded up and it's } \\ 10 & & \text { catching up with um England although my friend said if you } \\ 11 & & \text { go back to England, England's speeded up even more }\end{array}$

She draws heavily on the PROGRESS IS MOTION FORWARD (Kövecses, 2002: 137) metaphor. When she arrived, the place was 'backwards' (line 9). Furthermore, the metonymic expressions in lines 9-11 ('it's speeded up' / 'it's catching up' / 'England's speeded up') seem to relate PLACE as source domain to PROGRESS as target entity, suggesting that PLACE and

\footnotetext{
${ }^{12}$ The conflation/confusion of RASIM (refugee, asylum seekers, immigrants and migrants) terms in the British press is noted by Baker and M cEnery (2005) and Gabrielotos and Baker (2008).
} 
PROGRESS fit easily within the same mental model. Moreover, the repertoire 'Portugal is a developing country' can be used to avoid the perceived stigma of making stereotypical negative judgements of the Portuguese people through explicit us/them outgroup construction.

However, as (Abell et al., 2006) note, speakers often strategically switch between social and geographical constructions of political communities. In extract 5, my question as to perceptions of change in the Algarve region is taken up by Samantha in terms of how tourism has caused a social 'revolution' for the Portuguese people. Although my question was framed in a spatial representation (line 2), Samantha responds by stating what she believes the 'change' has meant for the 'Portuguese people', as a stereotyped collectivity:

\section{Extract 5}

$01 \quad \mathrm{KT}$ : ok (.) uhm (2.5) right changing the subject a little bit

02 d'you- do you think the Algarve has changed much in these

03 o whato nineteen, twenty years you've been here

04 S: yes!

$05 \quad$ KT: $\quad$ (2.0) can you say how?

06 S: uh: : m (1.0) well socially there's been a revolution here

07 (.) for the Portuguese people because of the tourism

$08 \mathrm{KT}: \mathrm{mm} \mathrm{hm}$

09 S: $\quad$ uhm (1.0) the er (.) the typical Portuguese family are are

10 um I believe you know their income per capita or however

11 you want to measure it it's it's much better than it used

12 to be (1.0) um (.) the Portuguese can now- the average

13

14

Portuguese family can now afford many more things than they

used to even dream of um there's more home ownership um many more people drive cars their children are educated fed clothed uh: : $\mathrm{m}$ and (.) so I suppose you can (.) generally describe that as progress (and there's) there's been a huge amount of progress

What also seems evident from this extract is that Samantha is also drawing upon a social representation of Portugal as a 'developing' country, i.e. a country that is undergoing (positively evaluated) change but has still not caught up with 'developed' countries. The 'huge amount of progress' (lines 17-18) that has occurred over the past two decades is directly attributed to 'tourism'; in other words, economic investment from the 'outside'. As the principal tourist markets in the Algarve are northern European, she seems to indirectly imply that economic development indicators such as home ownership, driving cars and children being 'educated fed clothed' (!) have improved through 'our' help, thus drawing on the social representation of wealthy northern European benefactors. Rhetorically, these types of representations may be employed to increase the force of the claim to legitimate belonging, since if the Portuguese are 'poor', then they need economic help, which 'we' can offer.

This brings us full circle back to the social legitimation of the phenomenon of lifestyle migration through its 'residential tourism' label. Although lifestyle migrants might distance themselves from 'tourists' in their individual positionings in talk, it does seem that in terms of collective positioning they might well be drawing on the underlying social representation that conflates the collective identities of northern European tourists, second home owners and more 'permanent' migrants in order to legitimatise their presence in the Algarve. 


\section{Concluding remarks}

One of the overall findings of my study of lifestyle migrant place-identity is that as individuals, these migrants seem to avoid deliberate self-positionings as members of a British community in the Algarve. As part of their constructed mode of elective belonging, they seem to want to project a sense of attachment to the host group. However, this is dilemmatic since they invariably do not speak Portuguese, which makes it difficult to claim social integration. When this issue arises in talk, it invariably causes trouble in identity work. One of the ways speakers attempt to resolve this trouble is by drawing on positive stereotypes of Portuguese people and representations of their behaviour in place, particularly at the more 'intimate' scale of their immediate neighbourhood. Another way they achieve an indirect sense of alignment with the Portuguese is by discursively positioning themselves as being 'outside' the British lifestyle migrant collective, or at least a certain sub-group of this collective: the ultra-wealthy who embody the elite identity constructed, for example, by place branding practices.

Yet, in reality, there is very little intergroup interaction in the 'Golden Triangle' area between lifestyle migrants and the local Portuguese, or indeed any other migrant group, at any meaningful social level. What does emerge from the interview data (and supports my own observations of the social practices and social relations among lifestyle migrants in the 'Golden Triangle') is a sense of collective self-positioning that stems from a shared representation of a social hierarchy based on economic resources and symbolic capital. This invariably places the Portuguese on a lower level than 'us', the British in the Algarve. Although this is often achieved by grounding such positionings indirectly in repertoires of place (e.g. Portugal is a poor/developing/backward country), indirectly this nonetheless positions the Portuguese as being in need of 'our' help and reinforces the frequently deployed repertoire which functions as a justification strategy for (collectively) being in the Algarve: we bring the money in.

The underlying ideology is therefore based on free-market capitalism, where the trading of land/property is supposed to be beneficial to both parties (i.e. 'us' and 'them'), and thus seeks to emphasise a form of social practice based on mutually advantageous exchange and cooperation, rather than highlighting power-based divisions between social groups. Furthermore, despite the inevitable physical and socio-cultural transformations which lifestyle migration provokes, many of which are potentially negative, it is generally encouraged by host societies as a particularly beneficial and thus 'legitimate' form of migration due to its discursive framing as a form of extended tourism. In regions such as the Algarve, which are economically dependent on tourism, this discursive framing serves many political interests and, moreover, feeds into the hegemonic ideological proposition that economic growth is a fundamental aspect of social wellbeing in local places. This goes some way to explaining why there is so little contestation of the lifestyle migration phenomenon. However, whilst this appears, on the surface at least, to indicate an unproblematic and even mutually beneficial relationship between lifestyle migrants in the Algarve and their hosts, this does not mean that such relationships are necessarily symmetrical (Benson and O'Reilly, 2009), since shifts in power and capital tend to consolidate differences among the various social groups who are, in one way or another, stakeholders in place.

An alternative view of lifestyle migration locates it in the real estate sector rather than the tourism sector. From this perspective, local economic elites, mainly property developers, stand to reap more economic benefits from the process than any other group, and therefore have a vested interest in perpetuating it (Mantecón, 2010). They are thus likely to form powerful lobbies at the level of both local and national territorial planning politics. As a prime example of how this may affect the material development of places, we need look no further than the 
proliferation of 'integrated resorts' currently under construction in the Algarve, as encouraged by the National Strategic Plan for Tourism. However, not only are English-speaking, northern European lifestyle migrants clearly the target market for the sale of such properties, but it is often the case that property developers and estate agents themselves are also northern Europeans. Moreover, in this particular area it is a well-known practice to purchase and register properties through off-shore companies, meaning that property purchase tax, municipal land taxes and capital gains taxes can be avoided. ${ }^{13}$ From this perspective, the economic benefits that lifestyle migrants bring to the region are not as clear as might be supposed. The underlying power geometries that are shaping the 'Golden Triangle' may well mean that the discourse of mutual advantageousness is constructed on very shaky ground.

\section{References}

Abell, J., Condor, S., \& Stevenson, C. (2006). 'We are an island': Geographical imagery in accounts of citizenship, civil society and national identity in Scotland and in England. Political Psychology, 27(2), 207-226.

Augoustinos, M., Walker, I., \& Donaghue, N. (2006). Social Cognition: An Integrated Introduction (2nd ed.). London: Sage.

Baker, P. \& M cEnery, T. (2005). A corpus based approach to discourses of refugees and asylum seekers in UN and newspaper texts. Journal of Language and Politics, 4(2), 197-226.

Baker, P., Gabrielatos, C., Khosravinik, M., Krzyżanowski, M., McEnery, T., \& Wodak, R. (2008). A useful methodological synergy? Combining critical discourse analysis and corpus linguistics to examine discourses of refugees and asylum seekers in the UK press. Discourse \& Society, 19(3), 273-306.

Benson, M . (2009). A desire for difference: British lifestyle migration to southwest France. In M. Benson \& K. O'Reilly (Eds.), Lifestyle Migration: Expectations,Aspirations and Experiences (pp. 121-136). Aldershot: Ashgate.

Benson, M. (2010). The context and trajectory of lifestyle migration: the case of the British residents of southwest France. European Societies, 12(1), 45-64.

Benson, M., \& O'Reilly, K. (2009). Migration and the search for a better way of life: A critical exploration of lifestyle migration. The Sociological Review, 57(4), 608-625.

Billig, M . (1997). Discursive, rhetorical and ideological messages. In C. M cGarty \& A. Haslam (Eds.), The Message of Social Psychology: Perspectives on M ind in Society (pp. 36-54). Oxford: Blackwell.

Cardoso Sousa, F. (2007). Almancil e as novas oportunidades de negócio: um estudo sobre o passado, o presente e o futuro de Almancil, sob o ponto de vista dos residentes. Loulé: Associação Empresarial de Almancil.

Chilton, P. (2004). Analysing Political Discourse: Theory and Practice. London: Routledge.

Gabrielatos, C., \& Baker, P. (2008). Fleeing, sneaking, flooding: A corpus analysis of discursive constructions of refugees and asylum seekers in the UK press, 1996-2005 J ournal of English Linguistics, 36(1), 5-38.

Gardner, R. C. (1985). Social Psychology and Second Language Learning. The Role of Attitudes and Motivation. London: Edward Arnold.

\footnotetext{
${ }^{13}$ In 2002/3, the Portuguese Government decided to attack offshore property ownership by producing a list of blacklisted countries and by introducing heavy penal taxes to discourage the practice. At that time, more than $50 \%$ of properties in the Freguesia of Almancil were found to be owned by offshore companies. The intense political lobbying that followed led to a further change to the law which reduced the penal taxes. Meanwhile, it did not take company administrators long to find other places with similar jurisdictions which were not on the Portuguese blacklist, and so the widespread practice continues today.
} 
Gibbons, J. (1936). Playtime in Portugal: An Unconventional Guide to the Algarves. London: Methuen.

Giddens, A. (1991). Modernity and Self-Identity: Self and Society in the Late Modern Age. Cambridge: Polity Press.

Grainer, J. (2004). Portugal and the Algarve Now and Then. n.p.: Quinta Publishing.

Gustafson, P. (2002). Tourism and seasonal retirement migration. Annals of Tourism Research, 29(4), 899-918.

Hoey, B. (2005). From Pi to Pie: M oral narratives of noneconomic migration and starting over in the postindustrial M idwest. Journal of Contemporary Ethnography, 34(5), 586-624.

Hoey, B. (2009). Pursuing the good life: American narratives of travel and a search for refuge. In M. Benson \& K. O'Reilly (Eds.), Lifestyle M igration: Expectations, Aspirations and Experiences (pp. 31-50). Farnham: Ashgate.

Hopkins, N., \& Dixon, J. (2006). Space, place, and identity: Issues for political psychology. Political Psychology, 27(2), 173-185.

Huber, A., \& O'Reilly, K. (2004). The construction of Heimat under conditions of individualised modernity: Swiss and British elderly migrants in Spain. Ageing \& Society, 24(3), 327351.

Huete, R., M antacón, A., \& M azón, T. (2008). Analysing the social perception of residential tourism development. In C. Costa \& P. Cravo (Eds.), Advances in Tourism Research (pp. 153-161). Aveiro: IASK.

Janoschka, M. (2008). Identity politics as an expression of European citizenship practice: Participation of transnational migrants in local political conflicts. In R. Anghell, E. Gerharz, G. Rescher \& M. Salzbrunn (Eds.), The M aking of World Society. Perspectives from Transnational Research (pp. 133-152). Bielefeld: Transcript.

Johnson, M. (1987). The Body in the M ind: The Bodily Basis of M eaning, Imagination, and Reason. Chicago: University of Chicago Press.

Kövecses, Z. (2002). M etaphor: A Practical Introduction. New York: Oxford University Press.

Mantecón, A. (2010). Tourism modernisation and social legitimation in Spain. International Journal of Tourism Research, 12, 617-626.

M arkus, H., \& Nurius, P. (1986). Possible selves. American Psychologist, 41(9), 954-969.

M artins de Brito, P., Ferreira, A., \& Costa, C. (2010). Cities, tourism and cultural planning - an integrated approach. In Destinations Revisited: Proceedings of the ATLAS Conference 2007 (pp. 39-54). Arnhem: ATLAS.

Mason, J. (2004). Personal narratives, relational selves: Residential histories in the living and telling. The Sociological Review, 52(2), 162-179.

M assey, D. (1993). Power-geometry and a progressive sense of place. In J. Bird, B. Curtis, T. Putman, G. Robertson \& L. Tickner (Eds.), M apping the Futures (pp. 59-69). London: Routledge.

M assey, D. (1999). Imagining globalization: Power geometries of time-space. In A. Brah, M. J. Hickman \& M. M ac an Ghaill (Eds.), Global Futures: Migration, Envornoment and Globalization (pp. 27-44). Basingstoke: Macmillan.

Mazón, T., Huete, R., M antecón, A., \& Jorge, E. (2009). Legitimación y crisis en la urbanización de las regiões turísticas mediterráneas. In T. Mazón, R. Huete \& A. Mantecón (Eds.), Turismo, urbanización y estilos de vida. Las nuevas formas de movilidad residencial (pp. 399-412). Barcelona: Icaria.

M odan, G. G. (2007). Turf Wars: Discourse, Diversity and the Politics of Place. M aldon, M A: Blackwell.

M oscovici, S. (1984). The phenomenon of social representations. In R. M. Farr \& S. M oscovici (Eds.), Social Representations (pp. 3-69). Cambridge: Cambridge University Press.

M oscovici, S. (2000). Social Representations: Explorations in Social Psychology. Cambridge: Polity Press.

M yers, G. (1994). Words in Ads. London: Edward Arnold. 
O'Reilly, K. (2000). The British on the Costa del Sol: Transnational Identities and Local Communities. London: Routledge.

O'Reilly, K. (2003). When is a tourist? The articulation of tourism and migration in Spain's Costa del Sol. Tourist Studies, 3(3), 301-317.

O'Reilly, K., \& Benson, M. (2009). Lifestyle migration: Escaping to the good life? In M. Benson \& K. O'Reilly (Eds.), Lifestyle M igration: Expectations, Aspirations and Experiences (pp. 113). Farnham: Ashgate.

Papastergiadis, N. (2000). The Turbulence of M igration. Cambridge: Polity Press.

Reisigl, M ., \& Wodak, R. (2001). Discourse and Discrimination: Rhetorics of Racism and Antisemitism. London: Routledge.

Savage, M., Bagnall, G., \& Longhurst, B. (2005). Globalization and Belonging. London: Sage.

Taylor, S. (2010). Narratives of Identity and Place. Hove: Routledge.

Thurlow, C., \& Jaworski, A. (2006). The alchemy of the upwardly mobile: Symbolic capital and the stylization of elites in frequent-flyer programmes. Discourse $\&$ Society, 17(1), 99135.

Triandafyllidou, A., \& Wodak, R. (2003). Conceptual and methodological questions in the study of collective identities. Journal of Language and Politics, 2(2), 205-223.

van Dijk, T. A. (1998). Ideology: A M ultidisciplinary Approach. London: Sage.

van Dijk, T. A. (2009). Critical Discourse Studies: A sociocognitive approach. In R. Wodak \& M. Meyer (Eds.), Methods of Critical Discourse Analysis (2nd ed., pp. 62-87). London: Sage. van Leeuwen, T. (2005). Introducing Social Semiotics. Abingdon: Routledge.

Waldren, J. (1996). Insiders and Outsiders: Paradise and Reality in M allorca (Vol. 3). Oxford: Berghahn Books.

Wetherell, M. (1998). Positioning and interpretative repertoires: Conversation Analysis and post-structuralism in dialogue. Discourse \& Society, 9(3), 387-412.

Wieczorek, A. (2009). This is to say you're either in or out: Some remarks on clusivity. Critical Approaches to Discourse Analysis Across Disciplines, 3(2), 118-129. 